IRA-International Journal of Management \& Social Sciences

ISSN 2455-2267; Vol.15, Issue 03 (June, 2019)

Pg. no. 65-80.

Institute of Research Advances

http://research-advances.org/index.php/RAJMSS

\title{
Reflections of Wage Discrimination on Poverty: Assessment of Indian Rural labour Market
}

\section{Santosh K. Singh ${ }^{1 \#}$, Anup K. Mishra ${ }^{2}$}

${ }^{1}$ ICSSR Post Doctoral Fellow in Economics, CSRD, JNU, New Delhi, India.

${ }^{2}$ Associate Professor in Economics, DAV PG College (BHU), Varanasi, India.

\#corresponding author.

Type of Work: Peer Reviewed.

DOl: http://dx.doi.org/10.21013/jmss.v15.n3.p2

\section{How to cite this paper:}

Singh, S.K., Mishra, A.K. (2019). Reflections of Wage Discrimination on Poverty: Assessment of Indian Rural labour Market. IRA-International Journal of Management \& Social Sciences (ISSN 2455-2267), 15(3), 65-80. doi:http://dx.doi.org/10.21013/jmss.v15.n3.p2

(C) Institute of Research Advances.

\section{(cc) BY-NC}

This work is licensed under a Creative Commons Attribution-Non Commercial 4.0 International License subject to a proper citation to the publication source of the work.

Disclaimer: The scholarly papers as reviewed and published by the Institute of Research Advances (IRA) are the views and opinions of their respective authors and are not the views or opinions of the IRA. The IRA disclaims of any harm or loss caused due to the published content to any party.

Institute of Research Advances is an institutional publisher member of Publishers International Linking Association Inc. (PILA-CrossRef), USA. The institute is an institutional signatory to the Budapest Open Access Initiative, Hungary advocating the open access of scientific and scholarly knowledge. The Institute is a registered content provider under Open Access Initiative Protocol for Metadata Harvesting (OAI-PMH).

The journal is indexed \& included in WorldCat Discovery Service (USA), CrossRef Metadata Search (USA), WorldCat (USA), OCLC (USA), Open J-Gate (India), EZB (Germany) Scilit (Switzerland), Airiti (China), Bielefeld Academic Search Engine (BASE) of Bielefeld University, Germany, PKP Index of Simon Fraser University, Canada. 


\begin{abstract}
In this research paper, we have tried to probe the effect or reflections of wage discrimination on poverty. It is found that the differences in the wage determination process in the public and private sectors may result in earning differentials across socio-religious groups. Many of the research community have been given data about discrimination in the labour market. In this particular paper, we have given the results of data interpretation for wage discrimination and its direct or indirect relation with poverty. The analysis has been presented for mainly three types of work; regular, casual and self-employed work. For the query of wage discrimination and its effect on poverty, we had divided the households into two parts, the first type of households whose household's MPCE is below the poverty line and second whose household's MPCE is higher the poverty line. The findings of the study make clear that the average daily wage for all type work of lower caste is less than the upper caste. The results also show that the poor household has found higher in lower caste in comparison to upper caste. The differences in the average wage-earning among the social groups for the same types of work may be the case of discrimination and poverty. The result argued to policymakers that they should frame an appropriate plan to address this issue and work for indiscrimination in the labour market and job creation in the rural areas.
\end{abstract}

Keywords: Labour market, wage discrimination, poverty.

JEL Code: I30, J31, J70.

\title{
Acknowledgements
}

We gratefully acknowledge to the Indian Council of Social Science Research (ICSSR), New Delhi to provide a grant under the Post-Doctoral Fellowship programme on the theme, "Discrimination and Poverty: A Study of Rural Labour Market in Uttar Pradesh", 2016-8, F.N.-3-6/2015-16/PDF. I also acknowledge to the Jawaharlal Nehru University (JNU), New Delhi for its permission to take this research work and giving their facility.

\section{1: Introduction}

\section{1: Economy and Labour Market}

India has witnessed an impressive GDP growth rate of over 6 per cent since the 1980s. Growth has been particularly rapid since the post-reform period of the 1990s. This high growth has contributed to a sustained increase in per capita income and a decline in absolute poverty, as also a modest improvement in the standard of living. However, this rapid economic growth has not significantly transformed the labour market and employment conditions in the country. While the improvement in employment conditions has been rather modest, the traditional low-productive employment continues to be a dominant feature of the economy. The overwhelming majority of workers are still engaged in informal and low-paid jobs. Moreover, female participation in the labour market has been quite low, as reflected by a declining trend over the years from 1983 to 2011-12 (ILER, 2014) ${ }^{1}$.

The demographic, technological and organizational processes over the last decades in India have profoundly affected the rural work and income structures. The most striking effect is the rising proportion of wage-labourers in the rural workforce and the persistence of rural poverty.

The Indian labour market is constituted by features like high unemployment and under-employment rate. This feature is unevenly distributed across different socio-religious groups as lower castes and females are more likely to be suffering from lower economic participation. The labour market outcomes of economic systems should be studied in the context of the development experience of that economy.

Besides, the dual labour market model argues that labour markets in developing countries like India remain segmented into primary and secondary labour markets. This is usually interpreted as a division between organized or formal and unorganized or informal sector. In this thesis, we assume that workers engaged in casual wage employment and workers engaged in regular wage employment compete in distinct labour markets. The segmentation of the labour market into the public and private sectors is another important source of wage differentials across socio-religious groups in India. The public sector plays a dominant role in the labour market for the highly qualified labour force. Wages in the public sector are determined by administrative procedure, whereas wages are determined by supply and demand forces in the private sector. This kind of differences in the wage determination process in the public and private sectors may result in earning differentials across socioreligious groups. Given such a situation, an individual calculates the expected lifetime earnings and when non-

\footnotetext{
${ }^{1}$ See- http://shodhganga.inflibnet.ac.in/bitstream/10603/203450/12/12_chapter\%204.pdf, pp-1, access on: $01 / 11 / 2018$
} 
monetary returns being equal, he/she has an option to choose between the public and private sectors depending on which sector yields a net advantage (Madheswaran, 1996) ${ }^{2}$.

\subsection{Concept of Discrimination:}

Discrimination is treatment or consideration of or making a distinction in favour of or against a person or thing based on the group, class, or category to which that person or thing belongs rather than on individual merit. This includes treatment of an individual or group based on their actual or perceived membership in a certain group or social category "in a way that is worse than the way people are usually treated". It involves the group's initial reaction or interaction influencing the individual's actual behaviour towards the group or the group leader, restricting members of one group from opportunities or privileges that are available to another group, leading to the exclusion of the individual or entities based on logical or irrational decision making. ${ }^{3}$

Thorat and Newman (2010) define discrimination as complete exclusion or denial of certain social groups such as the lower caste by higher castes in hiring or sale and purchase of factors of production (like agricultural land, non-land capital assets, and various services and inputs required in production process), consumer goods, social needs like education, housing, health services, and other services transacted through market and non-market channels, which is unrelated to productivity and other economic attributes.

\subsection{Discrimination and Labour Market:}

The issue of labour market discrimination has received less attention in mainstream discourse on labour studies in India. With the exception of gender, studies related to labour market discrimination associated with the institutions of caste, untouchability, ethnicity, religion, and other group identities and differential labour market outcomes are few in number. This applies to theoretical as well as empirical studies on labour market discrimination. The lack of systematic theoretical and empirical research on labour market discrimination has constrained our capacities to develop safeguards against discrimination and conceive well-founded equal opportunity policies in employment, education and other spheres for the discriminated groups (Thorat, 2008).

\section{4: Consequences of Discrimination in the Labour Market}

From the above discussed theoretical approaches, it is found that discrimination recreates a number of negative consequences. These negative consequences adversely distress to all economic productivity and its result, lower socio and economic growth. We can conclude the following consequences which affecting the labour market in a cyclic way: ${ }^{4}$

Discrimination recreates a number of negative consequences. These negative consequences adversely distress to all economic productivity and its result, lower socio and economic growth. Factor immobility, Economic efficiency, violation of individual choice and dignity of work are important consequences which affect the rural labour market.

\section{5: Discrimination and Poverty}

The consequences of the caste system in terms of equity and poverty are more serious than that for economic growth. Since the access to a source of income and economic reward under the caste system is determined by denial of educational, social, and economic rights, and resultant deprivation and poverty of the lower castes (Thorat, 2008. Disparities in economic and educational spheres in general and poverty of the lower castes like the former Untouchables and Other Backward Classes, in particular, are a direct outcome of the unequal entitlement of economic rights under the caste system (Ambedkar, 1936 in Thorat, 2008).

The issue of labour market discrimination is something which cannot be ignored mainly because of its adverse consequences on income distribution, poverty, and economic growth. In fact, the state in recognition of the visible inter-social group disparities between castes, ethnic groups, religious groups, and gender that are plaguing our society had to respond with policy initiatives - it just could not wait till academics came up with the optimal solution. As Thorat (2008) argues, in some cases, equal opportunity policies have preceded necessary research in theory and empirical evidence on labour market discrimination (Mishra, A. K, 2016).

To examine the uniformity of the consequences across the diverse terrestrial area, we have studied the broad social and cultural differences across the states and also within the states. We find very interesting consequences of discrimination of various outcomes in different places. Our aim of the study was the investigation of rural labour condition, mainly the result of wage discrimination and poverty in the study area.

\footnotetext{
2 Ibid, pp-2

${ }^{3}$ See- https://en.wikipedia.org/wiki/Discrimination access on 01.12.2018

${ }^{4}$ See for all defined consequences, Mishra, Anup K. (2016), Social Exclusion and Poverty; A case study of labour in eastern Uttar Pradesh, pp-
} 


\section{Review of Literature}

All available literature concerning the problem at hand must necessarily be surveyed and examined before a definition of the research problem is given (Kothati C. R., 2009). We had tried to review an optimum number of literatures concerned with the study. Following are the reflection of the review of the literature:

Bhatty (1974) estimated that the incidence of poverty was maximum for agricultural labourers' in comparison non-agricultural worker and cultivators. Thurow, C. (1978) studied poverty and discrimination among agricultural labourers in India and found that about 40 per cent of the agricultural labourers had very small holdings and their income was very low. As a result, most of the households of agricultural labourers were poor.

V.M. Dandekar \& Rath, N. (1979) suggested a lower minimum of 180 per capita per annum for the rural population and a higher minimum of 270 per capita per annum for the urban population at 1960-61 prices. The study estimated that in 1968-69 about 40 per cent of the rural population and a little more than 50 per cent of the urban population lived below the poverty line.

N.S. Iyengar\&Suryanarayanan M.H, (1983) found that the distribution of levels of living of households at the poverty line was positively skewed. Radhakrishna \& Reddy (1986) have stated that rural poverty is concentrated among the agricultural labourers in almost all the districts and cultivators and self-employed in backwards districts.

Sarma, P.(1987) argues that there is no association between income, poverty and generation change. Lieten (1992), presents that scheduled castes and scheduled tribes have very much come to the forefront in the public arena, poor peasants and agricultural labours also coming. In the study of a low-income household.

MacPherson, S., \& Silburn, R. (1998) have described the poverty that, one who is poor has not proper food and clothing in a normal situation and death consequences are high for them. Atkinson B. A. (1998), presented a three-way relationship between poverty, unemployment and social exclusion.

Blackrurn, C. (1999) has been found that in poverty the adults and children have more illness, more disabilities and shorter lives than their better-off counterparts. It is interpreted by Kabeer, N. (2000) that, there are many disadvantages groups of social exclusion. The book "Caste and Class in India"(2001), a combination of 20 papers, has reflected the various issues of caste, class and discriminations.

T. Alagumani \& Anjugam, M. (2002) found that when population and labour force showed a positive growth rate, unemployment and poverty ratio showed a negative growth rate. Sundaram, K; Suresh D Tendulkar (2003) inspects different social and economic groups shared the overall decline in poverty in the 1990s.

Ray, R. \& Lancaster, G. (2005) proposes an alternative outlook to the calculating of the poverty line. Results show that the poverty statuses in India for socially disadvantaged peoples are found worse than the official poverty calculations. Gardin C. et.al. (2006), has been analysed the role of gender wage discrimination on household poverty rates in several EU countries. They found that the effect of discrimination on poverty risk dramatically increases for individuals in households who largely depend on working female earnings, especially in the case of a single mother.

Thorat, Sukhadeo\&Attewell, Paul (2007), tried to explore the discrimination in the job application process in private sector enterprises in India. Lanjouw, Peter \&Murgai, Rinku (2008), covered five rounds of National Sample Survey data of, 1983, 1987/8, 1993/4, 1999/0 and 2004/05 which explore the employment in the nonfarm sector is seriously linked with education and social status.

The report "India Social Development Report 2010" (2010), the land question and the marginalised" is presented. The essays presented socio-economic conditions of marginalized sections of the population. AshwiniDeshpande (2011) provided a stimulating assessment of continuities and changes in caste disparities over the last two decades in his book "The Grammar of Caste Economic Discrimination in Contemporary India".

Ederington, Josh \&Sandford, Jeremy (2012) found an indirect link that market liberalization has a more pronounced effect in reducing discrimination. Thorat, Sukhadev(2013) tries to conceptualise the nature and divisions of the 'Exclusion - linked Deprivation' of socially disadvantaged groups particularly the Dalits in Indian Society.

\section{Objective and hypothesis of the Study:}

Based on the conceptual background, the main thrust of the paper is to analyse the discrimination in the Labour market in a comparative context to caste and gender. In the present paper, we intend to examine how discrimination is the cause behind poverty and identify the routes that could lead the discriminated groups out of poverty. With this objective, in order to get a clear direction for the investigation, we formulated a hypothesis 
that "Lower caste and female workers suffer from wage discrimination in labour market and are the reason for poverty".

\section{Methodology:}

In this study, both primary and secondary data have been used. Secondary data has been collected from $64^{\text {th }}, 66^{\text {th }}$ and $68^{\text {th }}$ round of NSSO reports and unit level data. The primary data has been collected with the help of a structured questionnaire and personal interview from various types of workers from two districts in Uttar Pradesh.

We have organised the districts in four quartiles as per descending order of their district level Gross Domestic Product (DGDP). The data for DGDP was taken from the government data source www.indiadata.go.in. The two districts have been selected randomly from higher district level Gross Domestic Product (DGDP) and other from lower DGDP. In this contrast, we have selected Allahabad district from higher DGDP (first quartile) and the second district Sant Ravidas Nagar have been selected from lower DGDP (fourth quartile).

We have selected one block have selected from each district randomly. The Blocks are Pratappur block and Bhadohi from Allahabad and Bhadohi district respectively. We have randomly selected Maharashtra village/gram of Allahabad district and Sonahar village/gram panchayat for our primary survey.

We have categorised the households in three strata on the prier house listing of the selected village. These three strata have been categorised on the basis of land holdings. The strata are: 'less than 5 biswa', ' $6-20$ biswa' and '21 biswa\& above' land holding. Keeping in the mind of better representation. We decided to take a 30 per cent sample household for the primary survey. These 30 per cent of households have been taken from all strata by the proportionate method. Total 193 households had been selected from all described strata for the primary survey.

\section{Analysis and Findings of Primary Data:}

In the present section, we had analysed the primary data in the context of wage and poverty.

\subsection{Wage Earnings of Regular Wage/Salaried Worker in the Study Area:}

As per the analysis, we found that the maximum number of regular wage/salaried people belonged to Upper caste, and for second and third number OBC and SC found respectively in the study area.

The result of the table (1) shows that the highest average wage earnings received by Upper Caste people in the survey area. The data reflect a new trend in the survey area that, in OBC regular worker is getting less wage/salary than SC caste. The table (1) is showing fewer wage earnings for OBC and SC than Upper caste. But the situation of regular wage earnings is not in favour of OBC. As it is a perception that, OBC's are higher in social and economic status than SC caste. But, if we observe about wage/salary earnings of regular employment the SC's are getting more than them.

We didn't find any female from Upper caste in regular employment ${ }^{5}$ in the study area. The highest daily average wage is getting by the SC female then $\mathrm{OBC}$ female regular employee. The Upper Caste people are getting regular wage/salary of Rs. 332.8, whereas OBC and SC are getting Rs. 191.5 and 231.7 respectively in 'temporary regular salaried in the private sector'. In the same way in 'Permanent regular salaried in private sector' the Upper Caste people were getting 496.7, but OBC people were getting Rs. 323.5 and for SC it was Rs. 296.6 (Table 2).

In the 'Temporary regular salaried in co-operative' only $\mathrm{OBC}$ female workers were found. Their per day average salary earnings are Rs. 233.3. In the temporary regular salaried in the government sector's OBC female workers are getting Rs. 337.6 whereas SC was getting only Rs. 78.3. In 'Permanent regular salaried in government sector'highest wage earnings was getting by the Upper Caste then by the OBC and SC respectively (Graphs 1 (A-H).

\subsection{Earnings of self-employed people in the Study Area:}

In table 3 we had tried to present daily average earnings of 'Self-employed' people in the survey area. It is well known that due to income measurement problem of this sector there are no authentic data available. In our study, we had tried to calculate per day / monthly average earnings for this sector and found the results as per depicted in the table.

The Upper Caste (Rs. 256.76) people were earning more than three times of SC (Rs. 96.95) self-employed people. The OBC self-employed people were getting Rs. 103.6 daily earnings, which are more than SC and less

\footnotetext{
${ }^{5}$ All samples have been taken on the basis of random and stratified random sampling method. Still it may be a sample error.
} 
than Upper Caste. It is found a drastic figure of 'Self-employed' Upper Caste females. On one side 'Selfemployed' OBC and SC female caste were earning very less amount, and on the other side, the Upper Caste female was earning plenty than both male and female of all castes self-employed people. Through table 5, we can assume a general thought that the SC caste people have lesser resources for doing any self- businesses. It might be a discriminatory situation or lack of opportunity for them.

Table 4 is an extension of the table 3 which shows the daily wage earnings of various activities under 'Selfemployment'.

Data of Table 4 shows that in self-farming (as a cultivator) people are generating very fewer earnings. It reflects that self-farming is not a beneficial business for any households. Only who have big land holdings can make some earning by self-farming. In our earlier analysis, we have found that there are fewer land holdings to SC caste people. So, it is obvious that they could not take any support to their family expenses by the selling of agricultural products. It shows the low status of SC caste in Indian society.

It is clear from the data shown in table 4 that, both the SC and OBC male and female were earnings negligible by self-employment of cultivating. No Upper Caste female was found the sector of self-employment. Only Upper Caste male was found, who was earning some honorific money from the sector of self-employment.

The non-farm sector is another in the self-employment works. In this sector, the Upper Caste male's earnings were highest than all other male and female. SC earnings are found high than OBC. A wide gap is found in Upper Caste female earnings than another caste female. The Upper Caste females were earning Rs. 369.87, whereas the OBC and SC caste female's earnings were only Rs. 30.35 and Rs. 68.33 respectively. It's clear a caste and gender-wise differences of earnings in this sector of self-employment. Graphs 2 (A) and 2 (B) present the clear picture of wage differences among all caste and gender.

\subsection{Status of Average Daily Wage of Casual Worker in the Study Area:}

If we observed the status of casual work in the employment sector we find that, the SC people's participation is found higher than all other castes. This section deals with per day earnings of casual worker of all caste. The table 5 shows that Upper Castes (Rs. 264.26) were getting more wage than OBC (Rs. 135.08) and SC (Rs. 125.89) caste. Here again, lower caste people getting low wage than upper caste which shows the clear low status of the SC as casual labour. This is, of course, a discrimination or opportunity gap situation for the SC caste. For female, the wage earnings for this work are found null for Upper Caste. It was Rs. 53.69 and Rs. 68.91 for $\mathrm{OBC}$ and SC respectively. It's again a dramatic pattern found for OBC and SC wage earnings. As we found that in self-employment the SC people were getting more earnings than $\mathrm{OBC}$, here again, the same pattern is found.

In this paper we had taken three types of casual work, viz; Agricultural casual labour, Non-agri. casual labour and Non-agri. contract labour. Table 6 presents per day average earnings for these sectors of casual work. From the data of table 6, we incorporated three graphs 3 (A), (B) and (C). These graphs give a clear picture of caste and gender-wise wage earnings of all sectors of casual work. Graph 3 (A) shows that only OBC and SC females are found as agriculture casual labour. SC female casual workers in the agriculture sector get Rs. 19.17 per day and OBC get Rs. 14.79.

The per day average earnings of non-agriculture workers (Graph 3 (B)) were highest for Upper Caste (Rs. 250.59) male. The SC and OBC males are getting Rs. 112.5 and Rs. 98.5 respectively. We didn't find any Upper Caste female as a non-agriculture casual worker in the study area. The OBC (Rs. 100.0) female are getting more per day average wage than SC (Rs. 59.81) female casual worker in the non-agriculture sector.

From graph $3(\mathrm{C})$, we found that in 'non-agriculture contract labour', the OBC caste male is getting the highest per day average wage of Rs. 388.32 than Upper Caste (Rs. 375.14) and SC (Rs. 218.13) male. For female, it is higher for SC (Rs. 300.0) than OBC (Rs. 116.67) female. No Upper Caste female are found in this sector of casual work.

\section{Reflections of Wage Discrimination on Poverty:}

For the query of wage discrimination and its effect on poverty, we had divided the family into two parts. The parameter for dividing the family is poverty line suggested by the Rangarajan Committee. The latest criteria for poverty measurement are for the year 2011-12, which have calculated by the committee as well as by many researchers. From these two parameters, the first type of divided family whose MPCE is greater than the determined poverty line and the second type of family whose MPCE is less than the determined poverty line.

It is clear by the table 7 that, the wage is higher for above poverty line families than the below poverty line families. This pattern has been found in all caste. So, it can be said on the analysis that, poverty exists in all caste, and the wage discrimination may also a reason behind it. In the support of the above assumption, we have 
presented the difference between average daily wage percentage in table 8 of the people 'above poverty line' and from 'below poverty line'. This difference is positive for all caste and is lowest for SC.

\section{Conclusion:}

The findings of the study make clear that the average daily wage for all type work of SC is less than Upper Caste. The difference in the average wage-earning among the social groups for the same types of work may be the case of discrimination and poverty. The study also shows the difference in the average wage earnings among the people living above the poverty line and below the poverty line. Hence our hypothetical statement 'Lower caste and female workers suffer from wage discrimination in the labour market and are the reason for poverty' is applicable.

The result shows that the lower caste people are not getting equal opportunity in the labour market, which seems a serious issue. Policymakers should frame an appropriate plan to address this issue and work for indiscrimination in the labour market and job creation in rural areas.

\section{References:}

[1]. Blackrurn, C. (1999). Poor health, poor health care: the experiences of low income. In M. Purdy, \& D. Banks, Health and Exclusion; Policy and practice in health provision (pp. 25-43). London: Routledge.

[2]. Dandekar, V., \& N., R. (1979). Poverty in India, Dimensions and Trends. Economic and Political Weekly, iv(17), 1131-1143.

[3]. Deshpande, A. (2011). The Grammar of Caste. New Delhi: Oxford University Press.

[4]. Iyengar, N. S., \& Suryanarayanan, M. H. (1983). On Poverty Indicators. Nimeographed Paper.

[5]. Kothari, C. R. (2009). Research Methodology: Methods and Techniques. New Delhi: New Age International (P) Limited.

[6]. MacPherson, S., \& Silburn, R. (1998). The meaning and measurement of poverty. In J. Dixon, \& D. Macarov, Poverty; A persistent global reality (pp. 1-15). London: Routledge.

[7]. Mishra, A. K. (2016). Social Exclusion and Poverty: A case study of Varanasi in eastern Uttar Pradesh. New Delhi: Shree Publisher and Distributers.

[8]. Mohanty, M., Ray, S., Trivedi, G., \& Sukumar, N. (2010). Landlessness and the Marginalized: A study of Kalahandi, Bhojpur, and Chittoor. In M. Mohanty, India Social Development Report 2010: The land question and the marginalized (pp. 224-242). New Delhi: Oxford University Press.

[9]. P. Perraju, S. (1987). Dimensions of Rural Poverty. New Delhi: Daya Publishing House.

[10]. R, R., \& S., S. R. (1986). Class Composition Poverty and Agricultural Development. Published in the Volume of Andhra Pradesh Economic Association fourth Annual Conference. Centre for Economic and Social Studies, Hyderabad.

[11]. Sharma, K. L. (2001). Caste and Class in India. New Delhi: Rawat Publications.

[12]. T. Alagumani, \& M., A. (2002). Poverty in India. Indian Economic Panorama, 12(2), 117-129.

[13]. Thorat, S. (2008). Labour Market Discrimination: Concept, forms and remedies in the Indian situation. The Indian Journal of Labour Economics, 51(1), 31-52.

[14]. Thorat, S. (2009). Dalits in India: Search for a Common Destiny. New Delhi: Sage Publications.

[15]. Thorat, S. (2013). Caste Social Exclusion \& Poverty. New Delhi: Critical Quest.

[16]. Thorat, S., \& Newman, K. S. (2010). Economic Discrimination in Modern India. New Delhi: Oxford University Press.

[17]. Thurow, C. (1978). Poverty and Discrimination. Khadi Gramodyo, 25(3), 155-156.

[18]. Lieten, G. K. (1992, July 18). Caste, Gender and Class in Panchayats Case of Barddhaman, West Bengal. Economic and Political Weekly, 1567-1574.

[19]. Atkinson, A. B. (1998, January). Social Exclusion, Poverty and Unemployment. Exclusion, Employment and Opportunity, 1-20. (A. B. Atkinson, Ed.) London, London: Centre for Analysis of Social Exclusion, London School of Economics.

[20]. Kabeer, N. (2000, October). Social Exclusion, Poverty and Discrimination: Towards an analytical framework. 31, 4. IDS Bulletin.

[21]. Ssundaram, K., \& D, T. S. (2003, December 13). Poverty among Social and Economic Groups in India in the 1990s. Economic and Political Weekly, 5263-5276.

[22]. Ray, R., \& Lancaster, G. (2005, January 1). On Setting the Poverty Line Based on Estimated Nutrient Prices. Economic and Political Weekly, 46-56.

[23]. Gardin, C., Rio, C. d., \& Canto, O. (2006, May). Poverty and Women's Labour Market Activity: The role of gender wage discrimination in the EU. Retrieved November 15, 2018, from Society for the Study of Economic Inequality: www.ecineq.org

[24]. Thorat, S., \& Atttewell, P. (2007, October 13). The Legacy of Social Exclusion; A Correspondence Study of Job Discrimination in India. Economic and Political Weekly, 4141-4145.

[25]. Lanjouw, P., \& Murgai, R. (2008, March). Poverty Decline, Agricultural Wages, and Non-Farm Employment in Rural India 1983-2004. Policy Research Working Paper-4858. The World Bank, Development Research Group, Poverty Team. 
[26]. Ederington, J., \& Sandford, J. (2012, October 25). Employer Discrimination and Market Structure. Retrieved April 27, 2013, from http://gatton.uky.edu/faculty/sandford/discrimination.pdf

[27]. Sodhaganga. (2018). Retrieved January 1, 2018, from Sodhaganga: 1.

http://shodhganga.inflibnet.ac.in/bitstream/10603/203450/12/12_chapter\%204.pdf

[28]. Wikipedia. (2018). Retrieved January 12, 2018, from https://en.wikipedia.org/wiki/Discrimination 


\section{Tables and Graphs}

Table 1: Average wage/ salary earnings (Rs. 0.00) per day received by regular workers in the study

\begin{tabular}{|l|c|c|c|c|c|c|c|c|c|}
\hline Caste & Male & Female & Total & Male & Female & Total & Male & Female & Total \\
\hline UC & 570.01 & - & 570.01 & 535.42 & - & 535.42 & 562.10 & - & 562.10 \\
\hline OBC & 353.42 & 139.08 & 289.12 & 319.05 & 118.75 & 294.01 & 325.92 & 127.46 & 292.85 \\
\hline SC & 327.78 & 164.40 & 321.94 & 438.57 & 197.27 & 422.48 & 365.61 & 180.83 & 357.02 \\
\hline Total & 437.94 & 145.41 & 419.94 & 387.13 & 134.45 & 364.16 & 415.05 & 139.32 & 394.37 \\
\hline
\end{tabular}

Source: Primary data 
IR A-International Journal of Management E' Social Sciences

Table - 2: Average wage/ salary earnings (Rs. 0.00) per day received by regular workers in various activity in the study area

\begin{tabular}{|c|c|c|c|c|c|c|c|c|c|c|c|c|}
\hline Primary Activity & \multicolumn{3}{|c|}{ Upper Caste } & \multicolumn{3}{|c|}{ OBC } & \multicolumn{3}{|c|}{ SC } & \multicolumn{3}{|c|}{ Total } \\
\hline \multicolumn{13}{|l|}{ Maharachha } \\
\hline P Act code & Male & Female & Total & Male & Female & Total & Male & Female & Total & Male & Female & Total \\
\hline Temporary regular salaried in priv. sector & 348.3 & - & 348.3 & 254.0 & - & 254.0 & 182.6 & - & 182.6 & 285.0 & - & 285.0 \\
\hline Permanent regular salaried in priv. sector & 650.0 & - & 650.0 & 428.0 & - & 428.0 & 264.8 & 164.4 & 258.1 & 364.5 & 164.4 & 355.8 \\
\hline Temporary regular salaried in co-operative & - & - & - & - & 139.1 & 139.1 & - & - & - & - & 139.1 & 139.1 \\
\hline Temporary regular salaried in gov. sector & 1031.0 & - & 1031.0 & - & - & - & 875.0 & - & 875.0 & 974.3 & - & 974.3 \\
\hline Permanent regular salaried in gov. sector & 570.0 & - & 570.0 & 353.4 & 139.1 & 289.1 & 327.8 & 164.4 & 321.9 & 437.9 & 145.4 & 419.9 \\
\hline \multicolumn{13}{|l|}{ Sonahar } \\
\hline Temporary regular salaried in priv. sector & 83.3 & - & 83.3 & 201.1 & 80.6 & 181.0 & 286.9 & - & 286.9 & 224.8 & 80.6 & 208.8 \\
\hline Permanent regular salaried in priv. sector & 394.4 & - & 394.4 & 281.7 & - & 281.7 & 522.2 & 197.3 & 441.0 & 355.3 & 197.3 & 347.4 \\
\hline Temporary regular salaried in co-operative & - & - & - & - & 233.3 & 233.3 & - & - & - & - & 233.3 & 233.3 \\
\hline Temporary regular salaried in gov. sector & - & - & - & 933.3 & - & 933.3 & 78.3 & - & 78.3 & 505.8 & - & 505.8 \\
\hline Permanent regular salaried in gov. sector & 1833.3 & - & 1833.3 & 1083.3 & - & 1083.3 & 1100.0 & - & 1100.0 & 1240.0 & - & 1240.0 \\
\hline Total & 535.4 & - & 535.4 & 319.1 & 118.8 & 294.0 & 438.6 & 197.3 & 422.5 & 387.1 & 134.5 & 364.2 \\
\hline \multicolumn{13}{|l|}{ All (Maharachha + Sonahar) } \\
\hline Temporary regular salaried in priv. sector & 332.8 & - & 332.8 & 209.9 & 80.6 & 191.5 & 231.7 & - & 231.7 & 257.2 & 80.6 & 247.6 \\
\hline Permanent regular salaried in priv. sector & 496.7 & - & 496.7 & 323.5 & - & 323.5 & 310.2 & 180.8 & 296.6 & 360.2 & 180.8 & 351.9 \\
\hline Temporary regular salaried in co-operative & - & - & - & - & 233.3 & 233.3 & - & - & - & - & 233.3 & 233.3 \\
\hline Temporary regular salaried in gov. sector & - & - & - & 933.3 & 139.1 & 337.6 & 78.3 & - & 78.3 & 505.8 & 139.1 & 285.8 \\
\hline Permanent regular salaried in gov. sector & 1131.3 & - & 1131.3 & 1083.3 & - & 1083.3 & 950.0 & - & 950.0 & 1057.3 & - & 1057.3 \\
\hline Total & 562.1 & - & 562.1 & 325.9 & 127.5 & 292.9 & 365.6 & 180.8 & 357.0 & 415.1 & 139.3 & 394.4 \\
\hline
\end{tabular}

Source: Primary data 

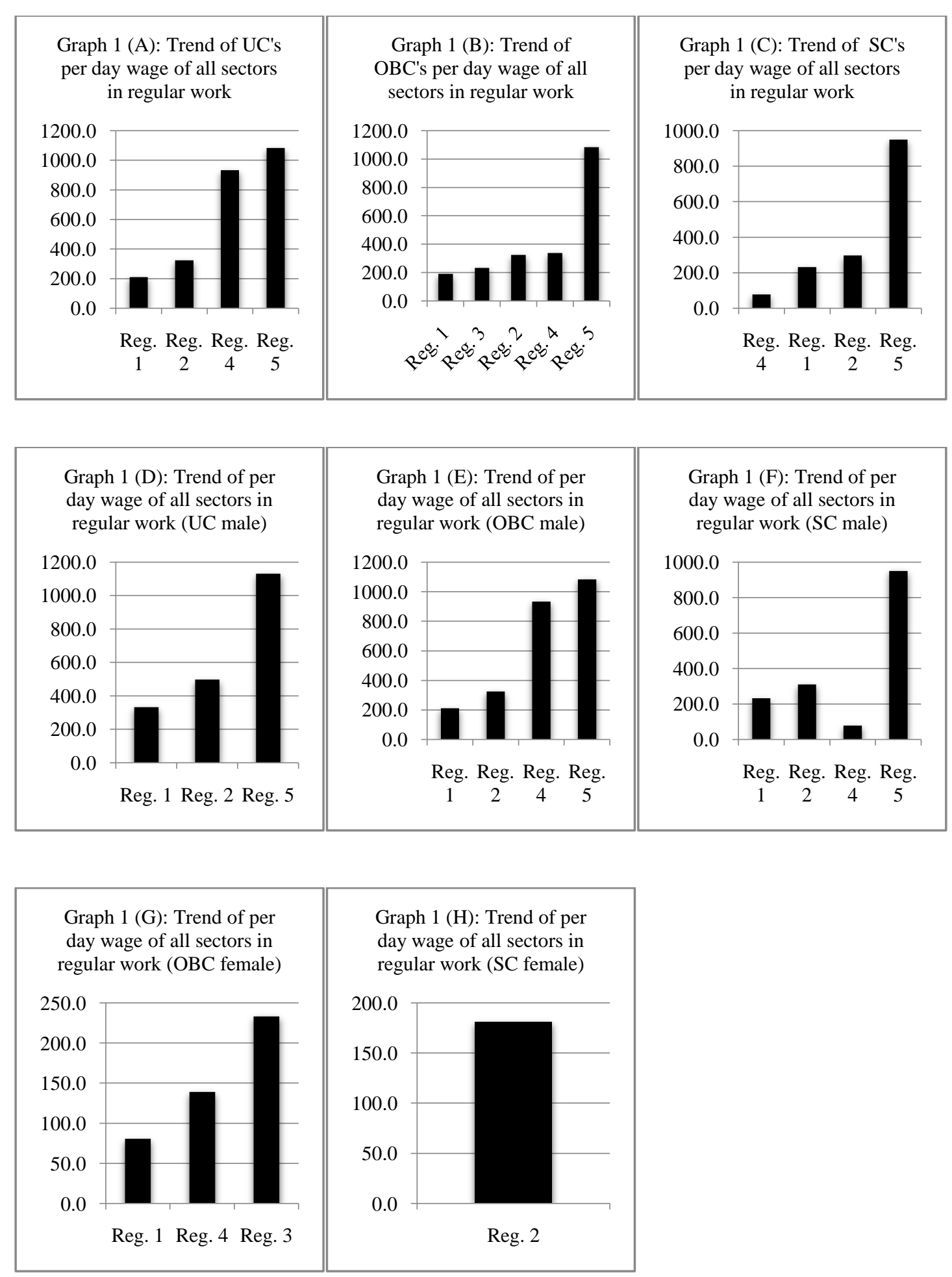

Note:

Reg. 1: Temporary regular salaried in private sector Reg. 2: Permanent regular salaried in private sector Reg. 3: Temporary regular salaried in co-operative Reg. 4: Temporary regular salaried in government sector Reg. 5: Permanent regular salaried in government sector 
Table 3: Average wage/ salary earnings (Rs. 0.00) per day received by 'Self-employed' in the study area

\begin{tabular}{|l|c|c|c|c|c|c|c|c|c|}
\hline \multirow{2}{*}{ Caste } & \multicolumn{3}{|c|}{ Maharachha } & \multicolumn{3}{c|}{ Sonahar } & \multicolumn{3}{c|}{ Total } \\
\cline { 2 - 10 } & Male & Female & Total & Male & Female & Total & Male & Female & Total \\
\hline UC & 214.22 & 369.87 & 220.98 & 462.50 & - & 462.50 & 252.41 & 369.87 & 256.76 \\
\hline OBC & 122.62 & 0.00 & 115.40 & 114.50 & 15.81 & 99.15 & 116.90 & 13.84 & 103.60 \\
\hline SC & 98.66 & 33.33 & 87.77 & 160.42 & 1.11 & 116.97 & 116.31 & 19.52 & 96.95 \\
\hline Total & 149.10 & 83.87 & 142.99 & 149.68 & 11.40 & 126.64 & 149.37 & 38.58 & 135.08 \\
\hline
\end{tabular}

Source: Primary data

Table 4: Average wage/ salary earnings (Rs. 0.00) per day received by 'Self-employed' in various activity in the study area-

\begin{tabular}{|c|c|c|c|c|c|c|c|c|c|c|c|c|}
\hline Primary Activity & \multicolumn{3}{|c|}{ Upper Caste } & \multicolumn{3}{|c|}{ OBC } & \multicolumn{3}{|c|}{ SC } & \multicolumn{3}{|c|}{ Total } \\
\hline \multicolumn{13}{|l|}{ Maharachha } \\
\hline P Act code & Male & Female & Total & Male & Female & Total & Male & Female & Total & Male & Female & Total \\
\hline Cultivator (Farmer) & 0.00 & & 0.00 & 0.00 & 0.00 & 0.00 & 21.43 & 0.00 & 17.65 & 8.57 & 0.00 & 7.69 \\
\hline Self-employed in nonfarm & 589.10 & 369.87 & 564.74 & 217.99 & & 217.99 & 278.87 & 133.33 & 258.08 & 362.95 & 251.60 & 354.04 \\
\hline Total & 214.22 & 369.87 & 220.98 & 122.62 & 0.00 & 115.40 & 98.66 & 33.33 & 87.77 & 149.10 & 83.87 & 142.99 \\
\hline \multicolumn{13}{|l|}{ Sonahar } \\
\hline Self-employed in nonfarm & 16.67 & & 16.67 & 143.03 & 30.35 & 135.99 & 160.42 & 3.33 & 142.96 & 143.36 & 21.34 & 134.64 \\
\hline Total & 462.50 & & 462.50 & 114.50 & 15.81 & 99.15 & 160.42 & 1.11 & 116.97 & 149.68 & 11.40 & 126.64 \\
\hline \multicolumn{13}{|c|}{ All (Maharachha + Sonahar) } \\
\hline Cultivator (Farmer) & 107.84 & & 107.84 & 4.00 & 8.33 & 5.24 & 21.43 & 0.00 & 15.79 & 47.68 & 4.55 & 39.36 \\
\hline Self-employed in nonfarm & 525.49 & 369.87 & 509.93 & 160.33 & 30.35 & 153.99 & 211.18 & 68.33 & 193.33 & 224.82 & 113.45 & 216.51 \\
\hline Total & 252.41 & 369.87 & 256.76 & 116.90 & 13.84 & 103.60 & 116.31 & 19.52 & 96.95 & 149.37 & 38.58 & 135.07 \\
\hline
\end{tabular}

Source: Primary data 

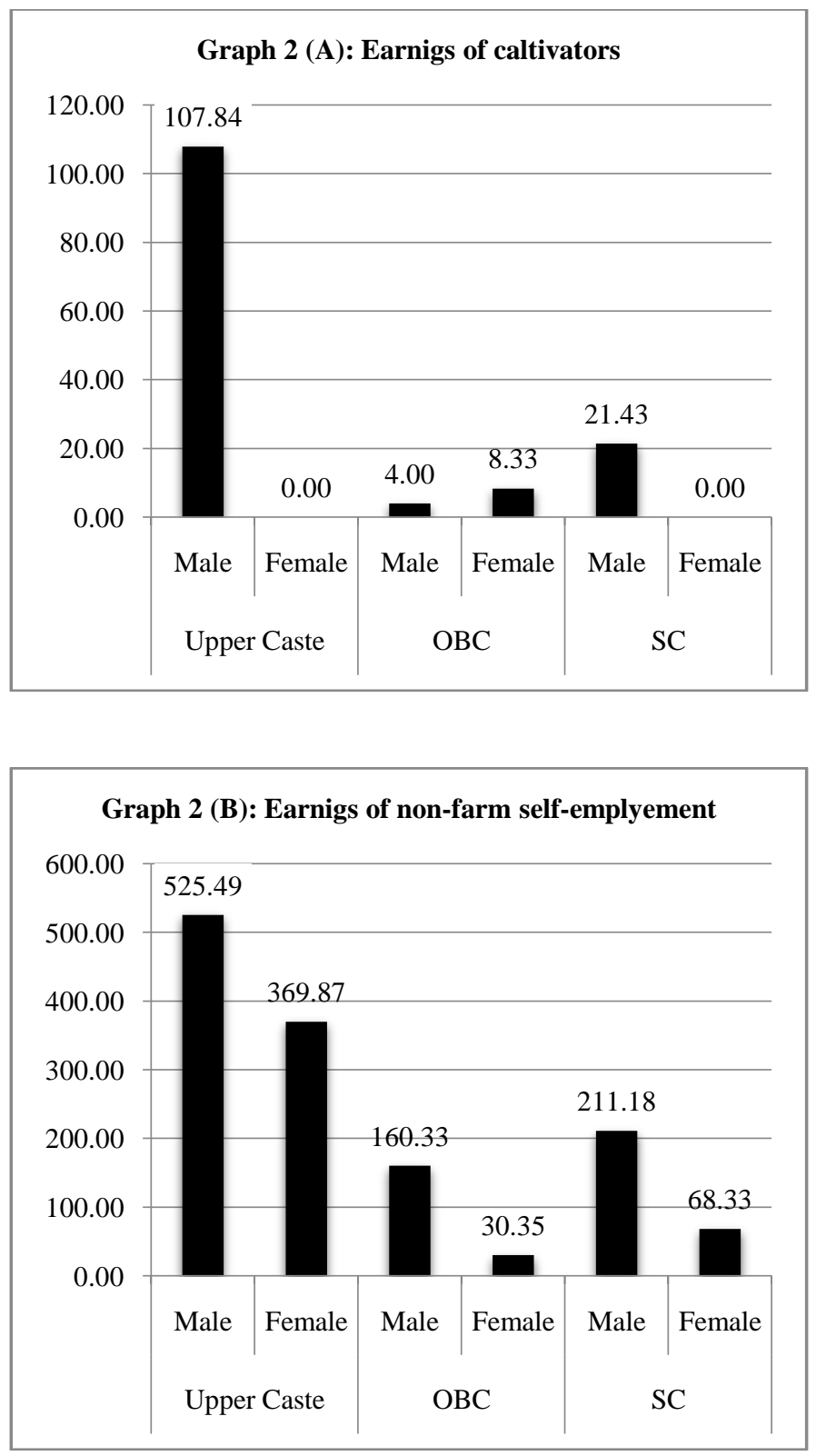
Table 5: Average wage/ salary earnings (Rs. 0.00) per day received by 'Casual worker' in the study area

\begin{tabular}{|l|c|c|c|c|c|c|c|c|c|}
\hline \multirow{2}{*}{ Caste } & \multicolumn{3}{|c|}{ Maharchha } & \multicolumn{3}{c|}{ Sonahar } & \multicolumn{3}{c|}{ Total } \\
\cline { 2 - 11 } & Male & Female & Total & Male & Female & Total & Male & Female & Total \\
\hline UC & 351.95 & 0.00 & 301.67 & 133.33 & - & 133.33 & 297.30 & 0.00 & 264.26 \\
\hline OBC & 388.32 & 6.67 & 333.80 & 98.55 & 61.53 & 91.61 & 152.88 & 53.69 & 135.08 \\
\hline SC & 163.43 & 89.38 & 155.20 & 111.05 & 59.81 & 99.52 & 137.65 & 68.91 & 125.89 \\
\hline Total (avg) & 219.80 & 60.69 & 200.71 & 106.29 & 60.50 & 97.01 & 154.78 & 60.56 & 138.82 \\
\hline
\end{tabular}

Source: Primary data

Table 6: Average wage/ salary earnings (Rs. 0.00) per day received by 'Casual worker' in various activity in the study area

\begin{tabular}{|c|c|c|c|c|c|c|c|c|c|c|c|c|}
\hline \multicolumn{13}{|l|}{ Maharachha } \\
\hline P Act code & Male & Female & Total & Male & Female & Total & Male & Female & Total & Male & Female & Total \\
\hline Agricultural casual labour & na & 0 & 0 & na & 6.67 & 6.67 & na & 19.17 & 19.17 & $\mathrm{Na}$ & 12.83 & 12.83 \\
\hline Non-agri. casual labour & 328.76 & na & 328.76 & & & & 115.15 & & 115.15 & 147.2 & & 147.2 \\
\hline Non-agri. contract labour & 375.14 & & 375.14 & 388.32 & & 388.32 & 218.13 & 300 & 223.25 & 280.3 & 300 & 281.09 \\
\hline Total & 351.95 & 0 & 301.67 & 388.32 & 6.67 & 333.8 & 163.43 & 89.38 & 155.2 & 219.8 & 60.69 & 200.71 \\
\hline \multicolumn{13}{|l|}{ Sonahar } \\
\hline Agricultural casual labour & & & & & 17.5 & 17.5 & & & & & 17.5 & 17.5 \\
\hline Non-agri. casual labour & 133.33 & & 133.33 & 98.55 & 100 & 98.65 & 111.05 & 59.81 & 99.52 & 106.29 & 67.12 & 100.14 \\
\hline Non-agri. contract labour & & & & & 116.67 & 116.67 & & & & & 116.67 & 116.67 \\
\hline Total & 133.33 & & 133.33 & 98.55 & 61.53 & 91.61 & 111.05 & 59.81 & 99.52 & 106.29 & 60.5 & 97.01 \\
\hline \multicolumn{13}{|c|}{ All (Maharachha + Sonahar) } \\
\hline Agricultural casual labour & & 0 & 0 & & 14.79 & 14.79 & & 19.17 & 19.17 & & 14.58 & 14.58 \\
\hline Non-agri. casual labour & 250.59 & & 250.59 & 98.55 & 100 & 98.65 & 112.5 & 59.81 & 104.18 & 116.65 & 67.12 & 110.6 \\
\hline Non-agri. contract labour & 375.14 & & 375.14 & 388.32 & 116.67 & 349.51 & 218.13 & 300 & 223.25 & 280.3 & 208.33 & 274.77 \\
\hline Total & 297.3 & 0 & 264.26 & 152.88 & 53.69 & 135.08 & 137.65 & 68.91 & 125.89 & 154.78 & 60.56 & 138.82 \\
\hline
\end{tabular}

Source: Primary data 

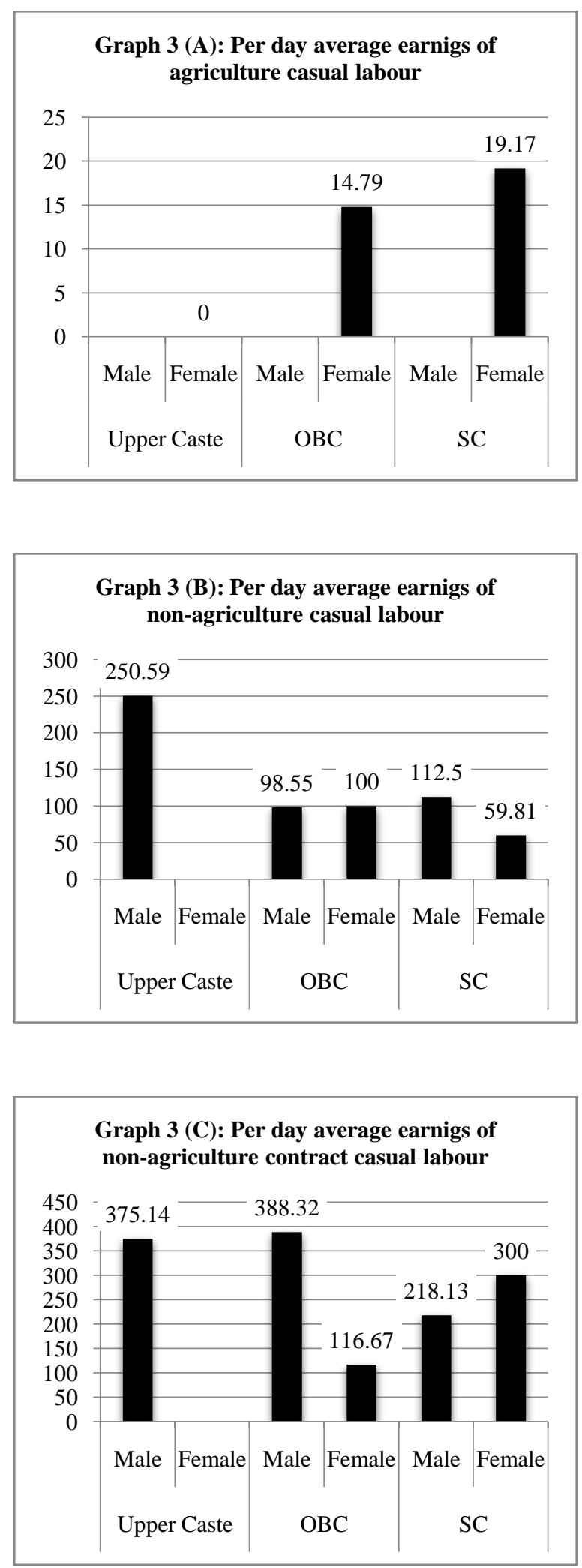
Table 7: Comparative average wage of below poverty line hh \& upper poverty line hh

\begin{tabular}{|l|c|c|c|c|c|c|}
\hline \multirow{2}{*}{ Caste } & \multicolumn{3}{|c|}{ Below poverty line hh } & \multicolumn{3}{c|}{ Above poverty line hh } \\
\cline { 2 - 7 } & Male & Female & Total & Male & Female & Total \\
\hline Upper Caste & 237.7 & 11.6 & 129.7 & 322.1 & 0.0 & 184.5 \\
\hline OBC & 113.5 & 10.7 & 62.4 & 140.2 & 10.6 & 80.6 \\
\hline SC & 133.1 & 12.3 & 73.6 & 176.5 & 3.8 & 108.6 \\
\hline Total & 139.9 & 11.6 & 76.7 & 206 & 5.9 & 119.3 \\
\hline
\end{tabular}

Source: Primary data

Table 8: Percentage difference in average per day from below poverty line hh to upper poverty hh

\begin{tabular}{|l|c|c|c|}
\hline Caste & Male & Female & Total \\
\hline Upper Caste & 73.8 & na & 70.3 \\
\hline OBC & 81.0 & 100.9 & 77.4 \\
\hline SC & 75.4 & 323.7 & 67.8 \\
\hline Total & 147.2 & 50.9 & 155.5 \\
\hline
\end{tabular}

Source: Primary data 